Lucjan TOMASIK

Embryology

\title{
SPECIFIC AND INDYVIDUAL DIFFERENCES IN MOTILITY BETWEEN SALMONID SPERMATOZOA
}

\section{GATUNKOWE I INDYẈIDUALNE RÓŻNICE W RUCHLIWOŚCI PLEMNIKÓW RYB LOSOSIOWATYCH}

\author{
Institute of Ich thyology \\ Department of Anatomy and Embryology of Fishes
}

\begin{abstract}
Spermatozoan motility was examined in Salmo trutta L., Salmo trutta m. lacustris L., Salmo gairdneri Rich. and Salvelinus fontinalis (Mitch.) from different spawning grounds and fish cultures. Fairly big differences were found in motility between spermatozoa examined under identical conditions. These differences were observed both between individual species (the spermatozoa of the lake- and sea-trout showed the highest viability and those of the rainbow trout the lowest) and between particular specimens; in this last case the differences seemed to be caused chiefly by different degrees of maturity of the gonads.
\end{abstract}

In connection with the investigation carried out in the Institute of Ichthyology on the fertilization of salmonid eggs, delayed in relation to the spawning (Cykowska et al., 1972), it appeared essential to examine the spermatozoa for their viability and possibility of transport.

Only few investigators conducted observations on the motility and survival of sal monid spermatozoa in ordinary water. Out of the species used for the present study, the rainbow trout received the most attention (Haempel, 1913; Scheuring, 1924, 1928; Schlenk, 1933; Lindroth, 1947; Medem et al., 1949; Dorier, 1951; Hamor, 1966; Babuskkin et al., 1971). Scheuring (1928), Werner (1934) and Allison (1961) dealt with 
the spermatozoa of the brook trout, Hamor (1966) with the spermatozoa of the seatrout, and Scheuring $(1928)$ and Ginzburg $(1963,1968)$ with those of the lake trout. However, no comparative studies have been published.

The spermatozoa of fishes become motile at the moment of coming into contact with water. In accordance sith the accurate description given for salmonid fishes by Scheuring (1924) and confirmed by Medem et al. (1949), the motion is vigorous, inertial and rotating for the first several seconds and next turns into forward motion, during which the spermatozoa travel, at first fairly quickly, towards the end more slowly until they stop at a moment. The head of the spermatozoon, however, keeps vibrating and performs rhythmic oscillatory movements. The period of motility of fish spermatozoa is not very long and, besides, it depends on a number of factors, in the first place, on the age of the reproducers (Scheuring, 1924, 1928), the temperature of the liquid environment (Schlenk and Kahmann, 1937; Lindroth, 1947) and its salinity (Scheuring, 1924; Ellis and Jones, 1939). A longer duration of motility is unnecessary, since having been placed in water, the fish eggs lose their fertility nearly as soon as the spermatozoa do (Lindroth, 1947). Nevertheless, this definite time of their motility (about 1 minute in salmonid fishes) seems to be biologically necessary for fertilization.

\section{MATERIAL AND METHOD}

This investigation was carried out using the spermatozoa of the seatrout (Salmo trutta L.) obtained from the River Rega at Trzebiatów, the spermatozoa of the lake trout (Salmo trutta m. lacustris L.) from Lake Wdzydze and those of the brook trout (Salvelinus fontinalis (Mitch.)) and rainbow trout (Salmo gairdneri Rich.) stripped from specimens grown in the ponds of the Regional River Laboratory IRS at Gdańsk-Oliwa. Milt was obtained from living mature males, 3-4 years old, in 1970-1972. Only the best quality milt (pure, uniform in consistence, easily evacuated by a light pressure) was used for this study.

The milt was placed in clean and dry test tubes, tightly corked, and transported in vacuum flasks (at $9.5-10^{\circ} \mathrm{C}$ ) to the laboratory at Szczecin, where it was kept at a temperature of $10^{\circ} \mathrm{C}$ throughout the period of experimentation.

The motility of the spermatozoa was examined under a microscope (300x magnification) adjusted for clear image so as to facilitate the observation of the response of the spermatozoa possibly soon after their coming into contact with water (2-4 seconds). In each case tap water ( $\mathrm{pH} 7.35)$ at about $11^{\circ} \mathrm{C}$ was used as the diluent medium. For examination a slight amount of sperm was transferred with the help of a bluntly ended thin wooden rod on to a cover slip and put on a droplet of water placed on a slide. In the samples used for study the dilution of sperm was approximately 1:100. At the moment of its mixing with water a stop-watch was set going. The time of forward motion (including the first period of vigorous motion) and that of oscillatory motion were measured, taking into account the general motion of most of the spermatozoa. In the light of the data 
obtained from liter ‘ure (among other authors, Ginzburg, 1963 and Popova, 1968), confirmed by our observations, the movement of all the spermatozoa must be distinguished from that of individual specimens, which is due to the fact that they do not begin moving simultaneously, for the water does not reach all of them at the same time. Attention was given to the number of moving spermatozoa relative to that of motionless ones, i.e., the non-activated or ,run out" ones. Measurements were taken three times for each sample and the mean was calculated.

\section{Results}

The results presented in Tables 1-4 show that the time of motion of spermatozoa (forward and oscillatory movements) examined immediately after spawning at $10^{\circ} \mathrm{C}$ is about 1 minute, being longer in the rainbow trout and brook trout (50-83 seconds) than in two other species i.e., lake-and sea-trout (51-66 seconds).

Table 1

The motility (in seconds) of spermatozoa of the sea-trout (Salmo trutta L.) examined at different intervals after spawning (in hours).

Numerator - forward motion; denominator - oscillatory motion; number preceding the fraction - sum of both values

\begin{tabular}{|c|c|c|c|c|c|c|c|c|c|c|}
\hline \multirow[t]{2}{*}{ Specimen No. } & \multicolumn{10}{|c|}{ No. of hours after spawning } \\
\hline & 0 & 12 & 24 & 36 & 48 & 60 & 72 & 84 & 96 & 108 \\
\hline 1 & $51 \frac{40}{11}$ & $48 \frac{39}{9}$ & $38 \frac{32}{6}$ & $38 \frac{33}{5}$ & $40 \frac{31}{9}$ & ${ }^{*} 6 \frac{25}{11}$ & $25 \frac{22}{3}$ & $32 \frac{23}{9}$ & few & \\
\hline 2 & $58 \begin{array}{l}42 \\
16\end{array}$ & $53 \frac{38}{15}$ & $54 \frac{30}{24}$ & $49 \frac{32}{17}$ & $46 \frac{28}{18}$ & $43 \frac{25}{18}$ & $33 \frac{17}{16}$ & * $32 \frac{19}{13}$ & few & \\
\hline 3 & $60 \frac{41}{19}$ & $58 \frac{39}{19}$ & $51 \frac{24}{27}$ & $51 \frac{27}{24}$ & $50 \frac{28}{22}$ & $-49 \frac{25}{24}$ & $55 \frac{17}{38}$ & $40 \frac{21}{19}$ & few & \\
\hline 4 & $51 \frac{32}{19}$ & $49 \begin{array}{l}29 \\
20\end{array}$ & $50 \frac{26}{24}$ & $39 \frac{22}{17}$ & few & few & & & & \\
\hline
\end{tabular}

* - about half the spermatozoa move

The time of motion of spermatozoa decreases, as they are kept out of water after spawning, but the decrease is not uniform in all species. For example, in the lake trout the motility of spermatozoa is nearly the same after 48 hours as it is at the beginning of the experiment, whereas in the rainbow trout it keeps at the initial level for the shortest time, only 24-36 hours. As can be seen from the results given in the tables, the forward motion also shows some specific differences. In the lake trout the time of forward motion ranges within the same limits immediately after spawning and 36 hours after it. The other species, especially the rainbow trout, are inferior to the lake trout in this respect in a varied but always distinct degree. 
The motility (in seconds) of spermatozoa of the lake trout (Salmo trutta m. lacustris L.) examined at different interwals after spawning (in hours). Numerator - forward motion; denominator - oscillatory motion; number preceding the fraction - sum of both values

\begin{tabular}{|c|c|c|c|c|c|c|c|c|c|c|c|}
\hline \multirow{2}{*}{$\begin{array}{c}\text { Specimen No. } \\
\mathrm{Nr}\end{array}$} & \multicolumn{11}{|c|}{ No. of hours after spawning } \\
\hline & 0 & 12 & 24 & 36 & 48 & 60 & 72 & 84 & 96 & 108 & 120 \\
\hline 1 & $66 \frac{46}{20}$ & $62 \frac{47}{15}$ & $76 \frac{50}{26}$ & $75 \frac{41}{34}$ & $92 \frac{27}{65}$ & $71 \frac{28}{43}$ & $72 \frac{33}{39}$ & few & few & & \\
\hline 2 & $63 \frac{45}{18}$ & $60 \frac{42}{18}$ & $53 \frac{44}{9}$ & $54 \frac{40}{14}$ & $62 \frac{29}{33}$ & $51 \frac{29}{22}$ & few & few & few & & \\
\hline 3 & $54 \frac{28}{26}$ & $52 \frac{29}{23}$ & $48 \frac{31}{17}$ & $50 \frac{28}{22}$ & $55 \frac{28}{27}$ & $54 \frac{30}{24}$ & $50 \frac{40}{10}$ & few & few & few & few \\
\hline 4 & $62 \frac{40}{22}$ & $60 \frac{39}{21}$ & $54 \frac{41}{13}$ & $56 \frac{40}{16}$ & $101 \frac{32}{69}$ & $50 \frac{33}{17}$ & $46 \frac{30}{16}$ & $47 \frac{30}{17}$ & $58 \frac{32}{26}$ & & \\
\hline
\end{tabular}

* - about half the spermatozoa move

Table 3

The motility (in seconds) of spermatozoa of the rainbow trout (Salmo gairdneri Rich.) examined at different interwals after spawning (in hours).

Numerator - forward motion; denominator - oscillatory motion; number preceding the fraction - sum of both values

\begin{tabular}{|c|c|c|c|c|c|c|c|c|}
\hline \multirow[t]{2}{*}{ Specimen No. } & \multicolumn{8}{|c|}{ No. of hours after spawning } \\
\hline & 0 & 12 & 24 & 36 & 48 & 60 & 72 & 84 \\
\hline 1 & $60 \frac{29}{31}$ & $86 \frac{18}{68}$ & $70 \frac{20}{50}$ & $59 \frac{20}{39}$ & few & few & few & \\
\hline .2 & $79 \frac{35}{44}$ & $72 \frac{31}{41}$ & few & few & & & & \\
\hline 3 & $58 \frac{27}{31}$ & $53 \frac{24}{29}$ & few & & & & & \\
\hline 4 & $50 \frac{26}{24}$ & $33 \frac{22}{11}$ & $55 \frac{20}{35}$ & $51 \frac{20}{31}$ & few & few & & \\
\hline 5 & $78 \frac{55}{23}$ & $73 \frac{30}{43}$ & $52 \frac{30}{22}$ & $46 \frac{26}{20}$ & $46 \frac{25}{21}$ & few & & \\
\hline 6 & $83 \frac{36}{47}$ & $85 \frac{24}{61}$ & $80 \frac{31}{49}$ & $62 \frac{25}{37}$ & few & few & few & \\
\hline
\end{tabular}

*. - about half the spermatozoa move 
The motility (in seconds) of spermatozoa of the brook trout (Salvelinus fontinalis (Mitch.)) examined at different interwals after spawning (in hours).

Numerator - forward motion; denominator - oscillatory motion;

number preceding the fraction - sum of both values

\begin{tabular}{|c|c|c|c|c|c|c|c|c|c|c|c|}
\hline \multirow[t]{2}{*}{ Specimen No } & \multicolumn{3}{|c|}{. } & \multicolumn{5}{|c|}{ No. of hours after spawning } & \multirow[b]{2}{*}{96} & \multirow[b]{2}{*}{108} & \multirow[b]{2}{*}{120} \\
\hline & 0 & 12 & 24 & 36 & 48 & 60 & 72 & 84 & & & \\
\hline 1 & $78 \frac{38}{40}$ & $75 \frac{36}{39}$ & $73 \frac{31}{42}$ & few & few & few & & & & & \\
\hline 2 & $70 \frac{39}{31}$ & $58 \frac{36}{22}$ & $40 \frac{33}{7}$ & few & few & & & & & & \\
\hline 3 & $63 \frac{33}{30}$ & $61 \frac{28}{33}$ & $60 \frac{27}{33}$ & few & few & few & few & & & & \\
\hline 4 & $80 \frac{40}{40}$ & $69 \frac{36}{33}$ & $65 \frac{34}{31}$ & $65 \frac{28}{37}$ & $64 \frac{35}{29}$ & $61 \frac{34}{27}$ & $60 \frac{40}{20}$ & ${ }^{*} 48 \frac{32}{16}$ & $45 \frac{30}{15}$ & & few \\
\hline
\end{tabular}

\section{DISCUSSION}

The viability of spermatozoa of the specimens examined was different and depended on species. There were also individual differences, especially well seen in the rainbow trout. In the light of these facts the practice of fish culturists, consisting in applying a mixture of semen obtained from several males for the fertilization of eggs, is justified. In this case the differences seem to be caused in a great measure by the varying degrees of maturity of the gonads. It must be stated in general that the viability of spermatozoa is remarkable and, as has been proved by Cykowska et al. (1972), spermatozoa retain their full fertilizing power even after a fairly long interval (2-3 days).

As the time passes, the period of motility becomes reduced and fewer spermatozoa move, which cannot be explained exclusively by the differences in the time of their coming into contact with water (as above) or, in other words, there occur individual differences between spermatozoa not only within a species but also within the milt of the same male.

The comparison of the results obtained in the present study with those given by other authors is impeded, among other things, by the fact that as a rule none of these writers, except for Hâmor, specified the temperatures at which they examined the motility of spermatozoa, or that they studied it at temperatures different from the temperature of water in spawning grounds $\left(4-9^{\circ} \mathrm{C}\right)$. Some of them confined their investigation exclusively to the measurement of the forward motion, which many investigators regard as 
their main or even only concern, because admittedly this very phase of motion plays the most essential part in fertilization.

The data from literature, on the motility of spermatozoa of particular species after many hours storage of the milt at the temperature found at its initial examination, are also fragmentary. In some cases the forms are studied as genera and their specific names are not given, or in other cases, the sort of motion dealt with is not mentioned (forward motion or whole period of motion including the oscillatory phase). The duration of motility of these spermatozoa will supposedly be still longer at lower temperatures (such as prevail in brooks at the commencement of spawning), but this remains to be demonstrated in further studies.

\section{REFERENCES}

Allison L., 1961: The effect of tricaine methanesulfonate (MS-222) on the motility of brook trout sperm. Progress. Fish-Cult., 23: 46-47.

Babuškin Ju.P., Savostianova, G.G., Capskaja M.K., 1971: Sravnenije kaKestva spermy u proizvoditelej raznych grupp radužnoj foreli. Izv. naữ n.-issl. Inst. Oz. i Rečn. Rybn. Choz. 74: 117-122.

Cykowska C., Sobociński A., Tomasik L., Winnicki A., 1974: Badania nad opóźnionym w stosunku do tarła zapłodnieniem jaj ryb łososiowatych.

Study on salmonid eggs fertilization delayed in relation to spawning. Zeszyty Naukowe Ak.R., Szczecin, 40, Rybactwo Morskie, III (in press).

Dorier A., 1951: Conservation de la vitalité et du pouvoir fécondant des spermatozoides de Truite arc-en-ciel. Trav. Labor. Hydrobiol. Piscic. Grenoble, Années 1949-1950, 75-85.

Ellis W., Jones J., 1939: The activity of the spermatozoa of Salmo salar in relation to osmotic pressure. J. Exp. Biol., 16: 530-534.

Ginzburg A.S., 1963: Soedinenije gamet bez aktivacji jaja u losossievych ryb. Ż. Uušč, Biol., 24 : $106-119$.

Ginzburg A.S., 1968: Oplodotvorenije u ryb i problema polispermii. Moskva, Izd. „Nauka”.

Haempel O., 1913: Fische I. Allgemeine anatomisch-physiologische Übersicht. - in. Hilzheimer M.: Handbuch der Biologie der Wirbeltiere, Stuttgart.

Hámor T.,Gibbons L., 1966:A sebes pisztráng (Salmo trutta L.) es a szivanyos pisztráng (Salmo irideus Gibbons) ivartermeheineh vizsgálata. Allat. közl., 53: 1-4.

Lindroth A., 1947: Time of activity of freshwater fish spermatozoa in relation to temperature. Zool. Bidr., Uppsala, Festskrift, 25: 165-168.

Medem F., Rötheli A., Roth H., 1949: Biologischer Nachweis von Befruchtungsstoffen bei Felchen und Flussforelle. Schweiz. Z. Hydrol., 11: 361-377.

Popova G.V., 1968: Poluđenije i chranenije molok belogo amura, belogo i pestrogo tolstolobikov. In Sb. „Novyje issledovanija po ekologii i rozvedeniju rastitalnojadnych ryb” M., Izd. „Nauka”: 180-186.

Scheuring Lo, 1924: Biologische und physiologische Untersuchungen an Forellensperma. Arch. Hydrobiol, Suppl. 4: 181-318.

Scheuring L., 1928: Weitere biologische und physiologische Untersuchungen an Salmonidensperma. Zool. Jb., Abt. Zool. Physiol., 45: 651-706.

Schlenk W., 1933: Spermatozoenbewegung und Wasserstoffionenkonzentration. Versuche mit dem Sperma der Regenbogenforellen. Biochem. Z., 65: 29-35. 
Schlenk W., jr., Kahmann H., 1937: Reaktionskinetische Untersuchungen der Bewegung der Forellenspermatozoen. Z. Vergl. Physiol., 24:518-531.

Werner W., 1934: A note on the use of physiological saline as defined herein as an aid in the artificial spawning of speckled trout. Trans. Amer. Fish. Soc. 64 th Ann. Meeting, Montreal, Canada: $346-350$.

Translated: mgr Jerzy Zawadzki

\section{GATUNKOWE I INDYWIDUALNE RÓŻNICE W RUCHLIWOŚCI PLEMNIKÓW RYB ŁOSOSIOWATYCH}

\section{Streszczenie}

Badano ruchliwość plemników Salmo trutta L., Salmo trutta m. lacustris L., Salmo gairdneri Rich., Salvelinus fontinalis (Mitch.) z różnych tarlisk i hodowli. Stwierdzono dość znaczne różnice w ruchliwości plemników badanych w identycznych warunkach. Różnice odnoszą się zarówno do poszczególnych gatunków (największą żywo ność przejawiają plemniki troci jeziornej i troci morskiej, a najmniejszą pstrąga tęczowego), jak i poszczególnych osobników, przy czym różnice w tym ostatnim przypadku zdają się być spowodowane głównie stopniem dojrzałości gonad.

\section{ВИДОВЫЕ И ИНДЫВИДУАЛЬНЫЕ РАЗЛИЧИЯ ПОДВИЖНОСТИ СПЕРМИЕВ JОСОСЕВЫХ РЫБ}

$\mathrm{P}$ e 3

Изучалось подвижность спермиев Salmo trutta I., Salmo trutta m. lacustris L., Salmo gairdneri Rich., Salvelinus fontinalis (Mitch.) происходяших из разных нерестилищ а также из прудов. Нашли довольно значительные различия подвижности спермиев при идентичных условиях опытов. Различия касаются как отдельных видов (самую большую живучесть проявляют спермии кумжи озёрной и морской, и самую низкую - радужной форели), так и отдельных особей, при чём, в последнем случае различия, как кажется, вызваны главным образом степенью зрелости гонад.

Address:

Received 14 III 1973

Dr Lucjan Tomasik

Insty tut Ichtiologii AR

Szczecin, ul. Kri arza Królewicza 4

Polska - Poland 